\title{
SILENCE USED IN ACEHNESE
}

\author{
${ }^{1 *}$ Asrah Raihana, ${ }^{2}$ Asmaul Husna, ${ }^{3}$ Fadhila Hayani; and \\ ${ }^{4}$ Putri Permata Sari Samosir \\ ${ }^{1,2,3,4}$ English Applied Linguistics Study Program, State University of Medan \\ Medan, Indonesia \\ *Corresponding author: asrahraihan04@gmail.com
}

\begin{abstract}
Language is very important in society. It is used to communicate with other people in everyday life. The understanding of language in communication becomes very important according to the main purpose of the use of the language itself which can be associated as a medium for delivering a message or information. As a tool of communication, language is not only conveyed orally, but also in silence. Every word has a meaning, silence also delivers a message and it has interpretations in meaning and purpose. The use of silence can also be found among Acehnese while having communication. Silence is a complex phenomenon and embodies diverse concepts. In most usages of the word, silence has some degrees of relativity and often refers to states, which may not be silent at all. While some situations require the use of silence in some contexts, the other researches were found that using of silence for unnecessary situation. The objective of this study is to analyze how silence used in Acehnese. What the meaning and function of silence used by Acehnese are. The method was Acehnese's conversations. From the data analysis, it showed that the respondents showed that silence found in conversation between Acehnese mostly used as a variety of politeness, to hide feeling ashamed, guilty, and angry. Besides that, it also showed a respect to elders, express agreement and disagreement. The silence used is also an influence of a custom in each culture descriptive qualitative. The source of the data was taken by recording of. In Acehnese culture, silence mostly used for showing polite behavior and respect toward people based on the context of the communication in social interaction.
\end{abstract}

Keywords: silence, Acehnese, ethnic, language.

\section{Introduction}

Language is very important in human society. It is used to communicate with other people in everyday life. The understanding of language in communication becomes very important according to the main purpose of language itself. It can be associated as a medium for delivering a message or information. Langacker (1968) states 
language is a symbol system based on pure or arbitrary convention infinitely extendable and modifiable according to the changing needs and conditions of the speakers. As a tool of communication, language is not only conveyed orally, but also in silence. If a word has meaning, a silence does too. It also delivers a message and has an interpretation of meaning and purpose.

Behnam and Nastaran (2014) states silence is a complex phenomenon and embodies diverse concepts. It is not speaking, so it seems the very opposite of language. However, a closer examination of words and speech reveals that silence can also convey various meanings and perform a range of functions. The researcher found that the functions and meanings can be changed according to the context, culture, setting, topic and interlocutor in communication.

Behnam and Nastaran (2014) conducted a research about silence in A Discourse Study of Rhetorical Silence in Persian and English Literature. The result showed that the cultural and the contextual dependency of silence realization and interpretation which strongly support the pragmatic concept of silence in Persian and English languages. The culture and context specific nature of silence in the given languages is closely linked to such attitude towards the aspects of rhetoric of silence within Persian and English literature.

Yuan (2015) Also did a research and found that in Chinese culture, silence is positive and it can express plenty meanings, such as agreement, praise, disagreement, protest, decision, respect, etc. While in Americans' attitude towards silence is negative which consider it as indifference, anger, shame, disgust, embarrassment, and disagreement.

Departing from those findings, the use of silence can also be found in Acehnese. Silence is a complex phenomenon and embodies diverse concepts. In most usages of the word, silence has some degree of relativity and often refers to states, which may not be silent at all. While some situations require the use of silence in some contexts, the other researches were found that using of silence for unnecessary situations.

From several previous researches above, there is a potency to reveal the use of silence in daily conversation among Acehnese. The aim of this research are to analyze how silence used, the meaning and function of silence among Acehnese while having conversation.

\section{Literature Review}

Language is a symbol system based on pure or arbitrary convention infinitely extendable and modifiable according to the changing needs, and conditions of the speakers. Language is the best means of self-expression. It is through language that humans express their thoughts, desires, emotions, feelings; it is through it they store knowledge, transmit message, transfer knowledge, and experience from one person to another, from one generation to another Langacker (1969). Language is an organization of sounds, of vocal symbols - the sound produced in order to convey some meaningful message. 
As a human being, we always do communication. Communication can be defined as the process of transmitting information and common understanding from one person to another, Keyton (2011). The word communication is derived from the Latin word, communist, which means common. The definition underscores the fact that unless a common understanding results from the exchange of information, there is no communication. The definition and identifies the important elements of the communication process (Cheney, 2011). Communication is transfer of information from one person to another, whether or not it elicits confidence. But the information transferees must be under and able to the receiver (GG-Brown, 2013). So communication is giving, receiving or exchanging ideas, information, signals, or message through appropriate media, enabling individuals or groups to persuade, to seek information, to give information, or to express emotions.

Nakane (2007) states silence takes various forms. When we look at various forms of silence, it makes us realise how complex and ambiguous, yet finely-tuned our use of silence in communication can be. One of the important functions of silence in social interaction is as a politeness strategy. Silence can be used to avoid unwanted imposition, confrontation or embarrassment in social encounters which may have not been avoided if verbal expressions had been used. At a wider sociocultural level, different norms may operate in terms of the context-specific distribution of talk and silence.

Scollon \& Scollon (1983) states that in Athabaskan Indian communities children's learning takes place by listening to and observing adults silently and not by displaying and discovering errors like Anglo American children.

While Nakane (2007) states that Silence can be created when comparisons between communicative styles of distinct communities are made by the participants. When this happens, cultural stereotypes are also reinforced, and perceptions of marked silences or unexpected volubility themselves can bring further silence or dominance of one group.

Although people generally think that silence can be used to communicate, in fact, people from different cultures have different understandings of silence.

\section{Research Method}

This study was descriptive qualitative, to describe the data carefully in accordance with the actual circumstances on silence used in family context in Acehnese. The source of the data was taken by recording of Acehnese's conversations. The data was identified from conversation which using silence by typing them into a note. After the data found, it will be analyzed based on the context and function.

\section{Result and Discussion}

From the data analysis, it showed that the respondents showed that silence found in conversation between Acehnese mostly used as a variety of politeness, to hide feeling 
Proceedings of the $1^{\text {st }}$ Annual International Conference on Language and Literature, 18-19 April 2018, Fakultas Sastra, UISU, Medan, Indonesia.

ashamed, guilty, and angry. Besides that, it also showed a respect to elders, express agreement and disagreement.

\section{Data 1}

\section{October $23^{\text {rd }} 2017$}

Context: In aunt's house, when a mother and her daughter were visiting their relative. The meaning of silence found in the conversation was to hide feeling ashamed.

Aunt : "jeb ie, chok kueh-kueh hai sinyak, bek male-male" (please drink and take the cake, don't be shy, dear)

Mother: "cok neuk, peu nyan galak. Teh... teh..nyo.. nyo..." (you might take what do you want to eat dear, which one do you want?

Daughter: silent

From the data above, the daughter was silent to respond her aunt statement and question. But finally she took the cake. This usually happens because she was ashamed. This situation usually happens when Acehnese children meet someone else besides family members. In Acehnese culture, this situation commonly happens for daughters. In this culture, it is not a problem, it seems as a polite attitude. The social function of silence here is for showing respect and polite attitude.

\section{Data 2}

\section{October $23^{\text {rd }} 2017$}

Situation: This conversation happens among siblings that convey the meaning of silence for holding anger.

$\begin{array}{ll}\text { Old sister } & \text { "jak pengon lon mita ija, siaat manteng" } \\ & \text { (Please accompany me to buy some clothes, sist) } \\ \text { Younger sister`: "Siat tek, lon tengoeh jai but hai kak, kaleh lon pugah uronyo } & \text { lon jai but, nyong tem si at tek beh" } \\ & \text { (Wait a moment, I am doing my tasks now, I have told you } \\ & \text { before that I was busy, if you don't mind, please wait for a } \\ & \text { moment, dear) } \\ \text { Old sist } & : \text { "jih lah kaleh ta pugah juoh juoh uro, sabe-sabe gabuk" } \\ & \text { (I have told you also about our planning today, you are always } \\ & \text { busy) }\end{array}$

The data above showed that the younger sister was silent and did not respond her older sister. It means that she did not want to be angry (hold anger). The function of silence used here are to avoid the conflict and extension the problem. In Acehnese culture, it is highly ethical between attitude and speech. The younger should not speak loudly to elder.

\section{Data 3}

\section{October $25^{\text {th }} 2017$}

Context: The conversation happened between the son and his father, which convey the meaning of silence in expressing disagreement. 
Proceedings of the $1^{\text {st }}$ Annual International Conference on Language and Literature, 18-19 April 2018, Fakultas Sastra, UISU, Medan, Indonesia.

Son : "yah lon lake izin yak jak u Idi ngon si yahya singoh beugoh"

(Dad, I would like to excuse for going to Idi with Yahya tomorrow morning)

Father : "pue but? Gadoh jak sabe." (What will you do there? You always go around)

Son : "maen-maen yah jak u pante, na mak cek si Yahya ideh, jet yah?" (We want to go to the beach, there is his aunt there, may I go dad?)

Father : ......... (Silent, no expression)

Son : "ka keh lah yah, hana jadeh le ku jak" (ok, I won't go)

The data above showed that his father was silent without expression, because he did not let his son went to Idi; it convey the meaning of disagreement. In Acehnese culture, the people use silence to interpret agreement and disagreement. For this function, people will not give any face expressions in silence. The function of silence use here is to provide disagreement.

\section{Data 4}

\section{November $1^{\text {th }} 2017$}

Situation: The conversation was between husband and wife that convey meaning of silence in expressing agreement.

Husband: "Peu na rencana thon baru intek?" (What is your plan for New Year?)

Wife : "Hana lom rencana, man si Ayu neuk jak u Malaysia, sang mangat cit" (I don't have a plan at all, but Ayu will go to Malaysia, I suppose to follow her)

Husband: "Lon na mentumeng bonus jalan-jalan u Singapore, kiban tem sitet? (I got bonus for two free tickets to Singapore, will you follow me?)

Wife (Silent and smile)"

"tanggai padom nyan? Nyak ta peu siap mandum"

(What date will we go? I will prepare all)

The data above showed that his wife did not respond his husband's question directly, she was silent then smiled. Here, the use of silence is to convey the meaning of agreement.

\section{Data 5}

\section{November $1^{\text {st }} 2017$}

Situation: The conversation is between siblings that conveys the meaning of silence in hiding feeling guilty.

Older sister : "dari pane mantong jino hat ban wo?" (Where did you go? Why did you go home too late?)

Younger sister: "jak bak si zizah siat buno, wo sikula pih ka tilat" (I went to Zizah's house. We finished the class late from the school)

Older sister : "Si jannah jak keu no hana kah, jie puegah wo sikula lage biasa" 
(Jannah was looking for you; she said that the class had finished like usual)

Younger sister: “....silent"

The data above showed that the younger sister did not respond her older sister. Because she lied about the time. The silence used in this situation in order to convey the meaning of hiding feeling guilty. The function of silence used here is to avoid a conflict.

\section{Conclusions}

From the result above, it showed that the use of silence in Acehnese culture is to express some meanings, such as to hide the feeling of shame, guilty and anger; to respect elder, and to express agreement and disagreement. Every meaning in silence used also provides some functions. Those are: Hide feeling of shame provide the function to respect and show polite attitude; Hide feeling of guilty provide the function to avoid the conflict and do not extend the problem; Hide feeling hold anger provide the similar function in guilty, to avoid the conflict and do not extend the problem; Respect elder provide the function to show polite attitude and behavior; and, Express agreement and disagreement, the function is to provide the feedback

Behnam and Nastaran (2014) states that the culture and context specific nature of silence in the given languages are closely linked to such attitude towards the aspects of rhetoric of silence within Persian and English literature.

The silence used also influences in custom of each culture. In Acehnese culture, silence mostly used to show polite behavior and respect toward elder people base on the context of communication in social interaction.

\section{References}

Behnam, Biook And Nosratzadegan. (2014). A Discourse Study of Rhetorical Silence in Persian and English Literature. in International Journal of Academic Research in Progressive Education and Development

Brown, G.G. (2015). Definition of Communication. In American Journal of Educational Research. (5).570-575. Available http://communicationtheory.org/definitionOf-communicationsAccessed June 3, 2013.

Cheney, G., et al. (2011). Organizational communication in An Age of Globalization, Waveland Pr Inc.

Clair, Robert N. The social and cultural construction in silence

Keyton, Joann (2011). Communication and Organizational Culture: A Key to Understanding Work Experiences, 2 ed, Sage Publishing Inc.

Langacker, Ronald W (1968). Language and its Structure: Some Fundamental Linguistic Concept. New York: Harcourt, Brace \& World.

Nanake, Ikuko (2007). Silence in intercultural communication. Amsterdam: John Benjamins Publishing 
Proceedings of the $1^{\text {st }}$ Annual International Conference on Language and Literature, 18-19 April 2018, Fakultas Sastra, UISU, Medan, Indonesia.

Scollon, Ron (1996). Discourse Identity, Social Identity, and Confusion. In Intercultural Communication Studies. VI:1

Yuan Quan, Yuan (2015). Analysis of Silence in Intercultural Communication. in International Conference on Economy, Management and Education Technology (ICEMET) 